\title{
The Role Professionalism in Managing Conflict at Work Place
}

\author{
Stewart Mbegu \\ School of Business, Mzumbe University, Mbeya, Tanzania \\ Email: smbegu@mzumbe.ac.tz, stewartmbegu@gmail.com
}

How to cite this paper: Mbegu, S. (2018) The Role Professionalism in Managing Conflict at Work Place. Open Access Library Journal, 5: e5014.

https://doi.org/10.4236/oalib.1105014

Received: October 30, 2018

Accepted: November 23, 2018

Published: November 26, 2018

Copyright $\odot 2018$ by author and Open Access Library Inc.

This work is licensed under the Creative Commons Attribution International License (CC BY 4.0).

http://creativecommons.org/licenses/by/4.0/

\section{(c) (i) Open Access}

\begin{abstract}
Workplace Conflicts in today's Business Environment seem to be inevitable; the most important thing is how these Workplace Conflicts are dealt to bring positive result to the organization. While Conflict management discipline focus on how can conflict be changed into opportunity to strength relationship between various stake holders in organization and improve the organization performance as whole, Professionalism provides a sustainable framework for problem and conflict solving at work places. The broad meaning Professionalism encompasses an attitude and Character of Being Came, Competency in the Field, Observing Codes of Conduct, Pursuit of Excellence and Enthusiastic Attitude which are keys for Conflict Solving at Work Place. Accountants and other professionals faces challenges, problems and conflicts in their business dealings and work places; therefore, this article based on existing literature, presents the discussion on role of Professionalism as key component in managing Workplace Conflicts.
\end{abstract}

\section{Subject Areas}

Management Organization

\section{Keywords}

Professionalism, Workplace and Conflicts

\section{Introduction}

Organizations regardless of their form, big or small, profit or not for profit, face workplace conflicts; these conflicts came from all corners and of different forms [1] [2] [3]. The going concern of any organization depends on the ability of the managers and worker to manage the Workplace Conflicts [1]. Though theories do not suggest to consider conflict in a negative way, that always conflict at work 
place is bad; still if not well managed it can have a significant impact on the going concern of the organization [4] [5]. The effort of address the conflicts at work place begun since 1970s during industrial revolution; most of organizations particularly in Europe turned to the use of alternative dispute resolution (ADR), to manage conflicts at work place [5]. Since then many theories have been developed on how conflict can be managed at work place, for instance normative conflict management theories [3].

Today's business environment is such complex, making conflict management at workplace in any organization to be an issue of interest; therefore, the business successes in such complexity depends on how management deals with conflicts in organizations [4] [5] [6]. In all levels of strategic management, the proper structure and system of proper handling the conflict in the organization is essentially very important for an organization to address conflicts timely, effectively and efficiently [5]. Since Workplace Conflicts provide bad images on customer you serve as well as on your co-workers, professionalism not only can create calm environment at work place but also can provide a framework for problem and conflict solving at work places [7] [8]. Therefore, this article presents the discussion on role of Professionalism as key component in managing Workplace Conflicts.

\section{Discussion}

\subsection{Definitions of Key Concepts}

According to Wilmot and Hocker, Conflict is "an expressed struggle between at least two interdependent parties who perceive incompatible goals, scare resources [9], and interference from others in achieving their goals". Work place refers to the physical location, settings, in which tasks are performed or interaction of people, in a process, system of producing services and goods to achieve organization objectives [10]. Therefore, conflict at work place can defined as struggle between workers and customer they serve as well as between co-workers, either between individuals or between groups [6] [11] [12]. Changed conflict into opportunity to strength relationship between various stake holders in organization and improve the organization performance as whole that, is called Conflict management [13].

\subsection{Sources of Conflict}

Conflicts may come from different sources, in an organization source conflict including; deference in beliefs, deference in interests, values and perceptions, deference in desires or differences in information; Also, scarcity of resources causing rivalries among individuals, group, firms and organization competing one another [4] [6] [14]. According to Gibson, Ivancevich and Donnelly, factors causing conflict among co-worker "include among others the work interdependence when two or more organizational groups depend on one another to complete their tasks, differences in goals, limited resources, reward structures, dif- 
ference in perceptions, unfair treatment as well as leadership management aspect" [15].

\subsection{Conflict Management}

According to Walker and Harris, Conflict management is practical if the organization will be encouraging behavioral approach to deal with Workplace Conflicts [15]. These behavioral approaches include; approach to avoiding perceptions and feelings of some is wrong somewhere so has to change, an approach of team work communicating the task together to solve a problem in group, an approach to exhibiting professions in solving problem and differences, an approach of identifying the potentiality of each team member in solving problems, shares feelings, accepting the reaction of each member in a group, treating each other with respect, negotiating instead of forcing are the best approaches to manage Workplace Conflicts [8] [15] [16].

\subsection{The Role Professionalism in Managing Conflict at Work Place}

A working place brings together individuals of different levels and sets skills, knowledge and education, also from different back ground in terms of beliefs, values, interests, or desires [16]. Professionalism can help to create calm environment at work place and provide a framework for problem and conflict solving at work places sustainably [7]. Professionalism is all about communicating appropriately and effectively, being ethical and responsible, demonstrating interpersonal, and problem-solving skills, being productive and team oriented [7]. It is also, including time management, being honesty, and integrity standard and high-quality work, dress appropriately for the job and appearing net and clean, conducting oneself with accountability, excellence and responsibility [16].

According to Marilyn Lindblad, Professionalism in an organization or at workplace refers to collections of an individual's characters, skills, standard behavior, attitude and team sprits that, brings individuals and groups to work in harmony with each other hence better organization performance [8]. Professionalism package conveys an air of accountability, excellence responsibility, competence, respect, efficiency and confidence; "The more professional you look, the more professional you feel, and the more professional and credible you'll appear to others" [7].

According to Louisiana State Civil Service, Professionalism a major component of assessing the interaction of an individual at workplace, a person exhibiting professional behavior at workplace can easily win credibility and confidence from others hence less conflict. Establishing and maintaining harmony environment at workplace is an important aspect for every employee; though it requires professional behavior practices [7] [16].

According to Dr Katherine Schaefer, badly handled conflict at workplace can create disaster, if professionalism approaches is not applied in handling conflict at work place and not embraced is solving problems, things can gate worse [17]. 
Also, Dr Katherine Schaefer insisted professionalism approaches in handling conflict by saying, "Once you fully understand, then you can speak" this is exhibition of professional behavior. There for, embracing professionalism approaches for sustainable Workplace Conflicts management in today's Business Environment, is inevitable [18].

\section{Conclusion}

Today's working places environments are complex and constantly evolving; in term of employees leaving job while others replaces, change in leadership style, remuneration system, competitive rivalry and cultural gaps-these complexities in which many firms operate make workplace conflicts inevitable. Professionalism approaches not only assist handling workplace conflicts but also provide a sustainable framework for managing Workplace Conflicts.

\section{Conflicts of Interest}

The author declares no conflicts of interest regarding the publication of this paper.

\section{References}

[1] Afzalur, R. (2011) Managing Conflict in Organization. 4th Edition, Transaction Publishers, Piscataway Township, NJ.

[2] Collins, S.D. (2009) Managing Conflict at Workplace. 2nd Edition, South-Western Cengage Learning.

[3] David, L. (1992) Normative Conflict Management Theories: Past, present, and Future. Institute for Development Research, Boston University, Boston.

[4] Bacal, R. (2004) Organizational Conflict: The Good, the Bad and the Ugly. The Journal of Quality and Participation, 27, 21-22.

[5] Barrister, E., Oni-Ojo Iyiola, O.O. and Osibanjo, A.O. (2014) Managing Workplace Conflicts in Business Environment: The Role of Alternative Dispute Resolution (ADR). European Journal of Business and Management, 6. https://www.iiste.org/

[6] Behfar, K., Friedman, R. and Brett, J. (2015) Managing Co-Occurring Conflicts in Teams. Group Decision and Negotiation, 25, 501-536. https://doi.org/10.1007/s10726-015-9450-x

[7] Louisiana State Civil Service. (2003) Professionalism in the Workplace, "Participant Manual Training and Workforce Development Comprehensive Public Training Program".

[8] Marilyn, L. (2005) Five Keys for Professionalism at Workplace. https://careertrend.com/five-keys-professionalism-workplace-28133.html

[9] Wilmot, W. and Hocker, L. (1998) Interpersonal Conflict. 5th Edition, McGraw-Hill, Boston, MA.

[10] Masters, M. and Albright, R. (2002) The Complete Guide to Conflict Resolution in the Workplace. Library of Congress, New York.

[11] Pondy, L. (1967) Organizational Conflict: Concepts and Models. Administrative Science Quarterly, 17, 296-320. https://doi.org/10.2307/2391553

[12] De Dreu, C.K.W., Harinck, F. and Van Vianen, A.E.M. (1999) Conflict and Perfor- 
mance in Groups and Organizations. International Review of Industrial and Organizational Psychology, 14, 376-405.

[13] Pekka, A. and Kalle, S. (2010) Organizational Communication and Conflict Management Systems a Social Complexity Approach. Nordicom Review, 31, 125-141.

[14] Blackard, K. (2001) Assessing Workplace Conflict Resolution Options. Dispute Resolution Journal, 56, 57-62.

[15] Gibson, Ivancevich and Donnelly (1994) Organizations, Irwin, Library of Congress.

[16] Walker, A. and Harris, L. (1995) Negotiation: Six Steps to Success. Bantam Books, Upper Saddle River.

[17] Katherine, S. (2003) Conflict Management Notes Advice for Negotiating Conflict in Your Professional Life. University of Rochester, Rochester.

[18] Acas (2009) Managing Conflict at Workplace. http://www.Acas.org.uk 